What Can Be Achieved By Special R\&D Funds When There is No Special Leaning Towards R\&D Intensive Industries?

Rahel Falk, Hannes Leo 


\section{What Can Be Achieved By Special R\&D Funds When There is No Special Leaning Towards R\&D Intensive Industries?}

\section{Rahel Falk, Hannes Leo}

WIFO Working Papers, No. 273

J une 2006 


\title{
What Can Be Achieved By Special R\&D Funds When There is No Special Leaning Towards R\&D Intensive Industries?
}

\author{
Rahel Falk and Hannes Leo \\ Austrian Institute of Economic Research (WIFO)
}

\section{$\underline{\text { Abstract: }}$}

This paper explores the effects of Austria's recent Special Funds initiative on the R\&Dexpenditures of its private corporate sector. It is the first one to approach the due evaluation from a macro perspective. First, simple descriptive statistics show that the noticeable delays in actual disbursements and the replacement of regular RTI-funds by these special funds reduce the latter's scope. Apparently, money can't work unless it is spent and "additional" funds at the expense of regular funds will trigger no additionalities. We then set up an econometric model to derive some inference on the relative importance of different public support channels on the business sectors's R\&D spending. Though the estimates suggest that direct government subsidies to R\&D-performing firms unfold great leverage effects, the dynamics of output growth as well as an R\&D-prone high-tech industry structure seem to be more important drivers of the business sector's R\&D intensity. Likewise, feeding special funds into the higher education sector will raise the R\&D-intensity of the business enterprise sector only if and to the degree that such funds contribute to Austria's overall economic prosperity or foster structural change towards more R\&D-intensive manufacturing. 
Introduction

The world's leading R\&D countries, most notably Sweden and Finland, but also the U.S. are typically characterized by a very high share of the corporate sector in total R\&D expenditures, while public R\&D outlays account for only a minor fraction. Outstanding R\&D performances of the private corporate sector do not descend upon countries like "manna from heaven". Instead, large publicly financed initial investments have often laid the grounds for subsequent success. For instance, several authors suggest that the favourable outcome of Finnish R\&D performance in these days took its starting point when the government introduced an urgent action plan for the promotion of research and technology development in 1996. Within the three years period 1997-1999 more than FIM 3 billion (about $€ 504$ Mio.) of fresh funds had been disbursed to enhance the operation of the national innovation system. The first evaluation of this program has come to the conclusion that the additional appropriation for research has been highly rewarding: the private business sector expanded its research investments; company profitability rose through increased research input; the number of product innovations grew, productivity was positively affected through a better trained workforce etc. (Prihti et all, 2000).

Adding new money is of course a straightforward answer to the Lisbon/Barcelona challenge - but how should this be allocated? To come up with some tentative answers, it is therefore vital to identify the key drivers of the business sector's R\&D engagement. Arguably, it is first and foremost the dynamics of output growth and the given industry structure that matter. If a country is specialised in industries typically characterised by a sound degree of R\&D intensity, then aggregate business R\&D intensity will generally be high as well. Accordingly, relevant government measures to stimulate R\&D undertakings at the firm level would have to address the external environment under which firms are operating so that research pays. Relevant policies include for instance competition and (de)-regulation policies, as well as patent protection. In a more narrow sense the government provides for a research-prone, favourable business setting by funding universities as well as research performed in public laboratories. The rationale is that scientific knowledge from academic research generates positive knowledge spillovers and thereby facilitates private business R\&D and fosters productivity of the corporate world. Apart from 
those indirect measures, the government can also stimulate business R\&D in a more direct way, either through fiscal incentives, or by means of direct financial support.

In December 2000, the Austrian Federal Government announced an urgent action plan, the so-called "Offensiv-Programm I" to promote the goal of increasing the national R\&D quota in terms of gross domestic product (GDP) from 1,8\% in 2000 to $2,5 \%$ of GDP in 2005. Additional funds amounting to $€ 508.7$ Mio were agreed to in order to boost Austrian sciences and technology developments and to draw nearer to the Barcelona aims.

This paper deals with the effects on the business sector's R\&D-intensity that can be expected to result from these funds. The structure of the paper runs as follows: Section 2 explores how the recent special funds initiative fits into Austria's general strategy in the fields of Research, Technology and Innovation (RTI henceforth). We look at both, the institutional changes and the allocation of the money. In doing so, we put particular emphasis, first, on the money that has actually been disbursed, and, second, on possible replacement effects. We find that special funds contribute to increases in government financed RTI-expenditures. At the same time, however, it also proves true that such increases were accomplished by regular funds in the preceding years and that the latter were in parts substituted by money from the Offensive-Programm. The third section develops the methodical approach to the impact assessment of different support channels on the R\&D intensity of the business sectors. Before we present the results in section five, the fourths section displays some summary statistics of the relevant variables of the econometric model. The estimation results return elasticities with respect to direct, indirect as well as implicit government measure which are then used to calculate the net effect of Austria's recent special funds initiative on the R\&D intensity of the business sector. Section six concludes. 


\section{Austria's Route to Barcelona}

\subsection{Institutional Changes}

At the turn of the millennium the Austrian innovation system had been characterized by considerable overlaps in functional responsibilities and extensive inefficiencies in the funding system were prevailing (Leo et al., 2002). To meet the challenge of an R\&D quota of $2.5 \%$ by 2006 or $3 \%$ by 2010 , respectively, Austria has since then undertaken great efforts to simplify and reorganize its funding structure and to increase its budget for R\&D measures.' In 2000 the establishment of a Council for Research and Technolgy Development marked the beginning of an overdue streamlining process. Since then and in contrast to former advisory bodies, the Council advises all ministries involved in science, research, and development and comments on all major projects before a final decision is made. Starting from September 2004 it has been running as an independent legal entity. The Council defines the priorities of the Austrian innovation policy and published a "National Research and Innovation Plan" in 2002 as the first coherent and strategic document of Austrian Innovation and Technology Policy. Recently, this key documented has been updated (see Austrian Council, 2002B and 2005). It should be emphasized, however, that neither the Council's strategies, nor recommendations are binding except for its recommendations on the use of the special funds, with which it has been entrusted since January 2001.

Another new player in the Austrian Innovation System is the "National Foundation for Research, Technology and Development". It has been founded in spring 2004 by the three technology ministries ${ }^{2}$, the ministry of finance and the Austrian Reserve Bank, where the latter provides for the funds (in concert with the funds from the European Recovery Program). The new foundation concentrates on middle- and long-term goals of research and technology policy and promotes qualitatively high-standing

\footnotetext{
' Details of the following passage can be found in Leo et al., 2004.

2 In Austria, the so-called technology ministries comprise the federal department for traffic, innovation and technology, the federal department for education, science and cultural affairs, and the federal department for economic affairs and employment.
} 
projects with an annual budget of approximately 125 Mio $€$. To optimize existing structures, the Council submits non-binding proposals to the foundation on how to distribute the money.

Finally, in June 2004 the Austrian Research Promotion Agency (FFG) was set up as an umbrella organization that groups the formerly independent institutions Austrian Space Agency (ASA), the Bureau for Innovation and Technology (BIT), the Industrial Research Promotion Fund (FFF) and the Technologie Impulse Gesellschaft (TIG) under one roof. The 2004 budget of the FFG amounts to 12.12 Mio $€$, but for the following three years increases of about $50 \%$ are envisaged. Additionally, considerable parts of the special funds for science and technology are channelled into the economy through the FFG.

\subsection{Special Funds for Research and Development}

In December 2000, the Austrian Federal Government announced an urgent action plan, the so-called "Offensiv-Programm I" to promote the goal of increasing the R\&D quota in terms of gross domestic product (GDP) from $1.8 \%$ in 2000 to $2.5 \%$ of GDP in 2005. Additional funds amounting to $€ 508.7$ Mio were agreed to in order to boost Austrian sciences and technology developments. These additional funds were to be evenly distributed within the next three years so that in each year 2001-2003 extra money of some $€ 169$ Mio would be available. In relative terms fresh funds of $€ 169.57$ Mio accounted for about $13.8 \%$ of the federal state's R\&D expenditures in 2000 and of some $4.2 \%$ of total Austrian R\&D expenditures in 2000.

When classified by purpose the Council agreed to channel $32 \%$ of the funds to basic and $35 \%$ to applied research programs. $22 \%$ of the money was destined for promoting market-oriented research and development and $12 \%$ was intended for advancing technology transfers and innovations (Austrian Council, 2002A, pp. 32-33). In absolute terms these shares translate into figures of approximately $€ 161$ Mio, $€ 176$ Mio, $€ 113$ Mio and $€ 60$ Mio, respectively (see Table 1). With respect to the implementation sectors the Council agreed to allocate roughly the same shares of the special funds to companies (37\%) and universities (36\%). 
Table 1: Distribution of special funds by performance sector and purpose Commitments

\begin{tabular}{l|rr} 
& in Mio. $€$ & in \% \\
\hline Distribution of funds by purpose & & \\
Basic research & 160.51 & 31.6 \\
Applied research & 175.91 & 34.6 \\
Experimental development & 112.57 & 22.1 \\
Technology transfer, innovation, others & 59.72 & 11.7 \\
\hline Total & 508.71 & 100.0 \\
& & \\
Distribution of funds by performance sector & & 35.6 \\
Universities & 180.95 & 27.6 \\
Non-university research institutes & 140.47 & 36.8 \\
Companies & 187.29 & 100.0
\end{tabular}

Source: Austrian Council for Research and Technology Development, Annual report 2000-2002

The remaining sum of about $€ 140$ Mio was envisaged to benefit non-university research centers which encompass both public sector institutions as well as establishments organized under private law.

The Council has launched initiatives to promote emerging technology fields for the future. Recommendations on biotechnology (15.5\%), information- and communication technologies (12.2\%) as well as on mobility/traffic (11.1\%) account for considerable shares of the total. Other trendsetting industries such as nanotechnologies attracted only minor parts ( $€ 184$ thousand, i.e. $2.6 \%$ of the first special funds tranche), but the Council recommended to spend 12.6 Mio $€$ of the follow-up Offensivprogramm II on the Nano-initiative. ${ }^{3}$

Some of the research promotion schemes endowed with special funds are new and owe their initiation to the availability of fresh funds. ${ }^{4}$ Nonetheless, large shares of the

\footnotetext{
3 The follow-up program provides $€ 600$ Mio for the period 2004-2006. The program is still running and therefore will not be evaluated in this paper.

4 Programs which can be directly related to the Offensiv Programm I include, for instance, FIT-IT for innovations in information and communication technology, the genome research program GEN-AU, the Austrian space application program ASAP, the ARTIST program for satellite development, the
} 
special funds have been used to secure financing of existing programs. Most notably the two major federal support schemes addressing R\&D promotion in the private corporate sector (FFF) and in the public domain (FWF) have been awarded with additional funds amounting to $€ 58$ Mio and $€ 36$ Mio, respectively. In relative terms assistance to these institutions account for $19 \%$ of the total sum allocated. Allowances to the advantage of the competence centres are of similar magnitude (approximately $€ 80$ Mio in total).

Figure 1: Government financed research and experimental development carried out in Austria - Disbursements (in constant 2000 prices)

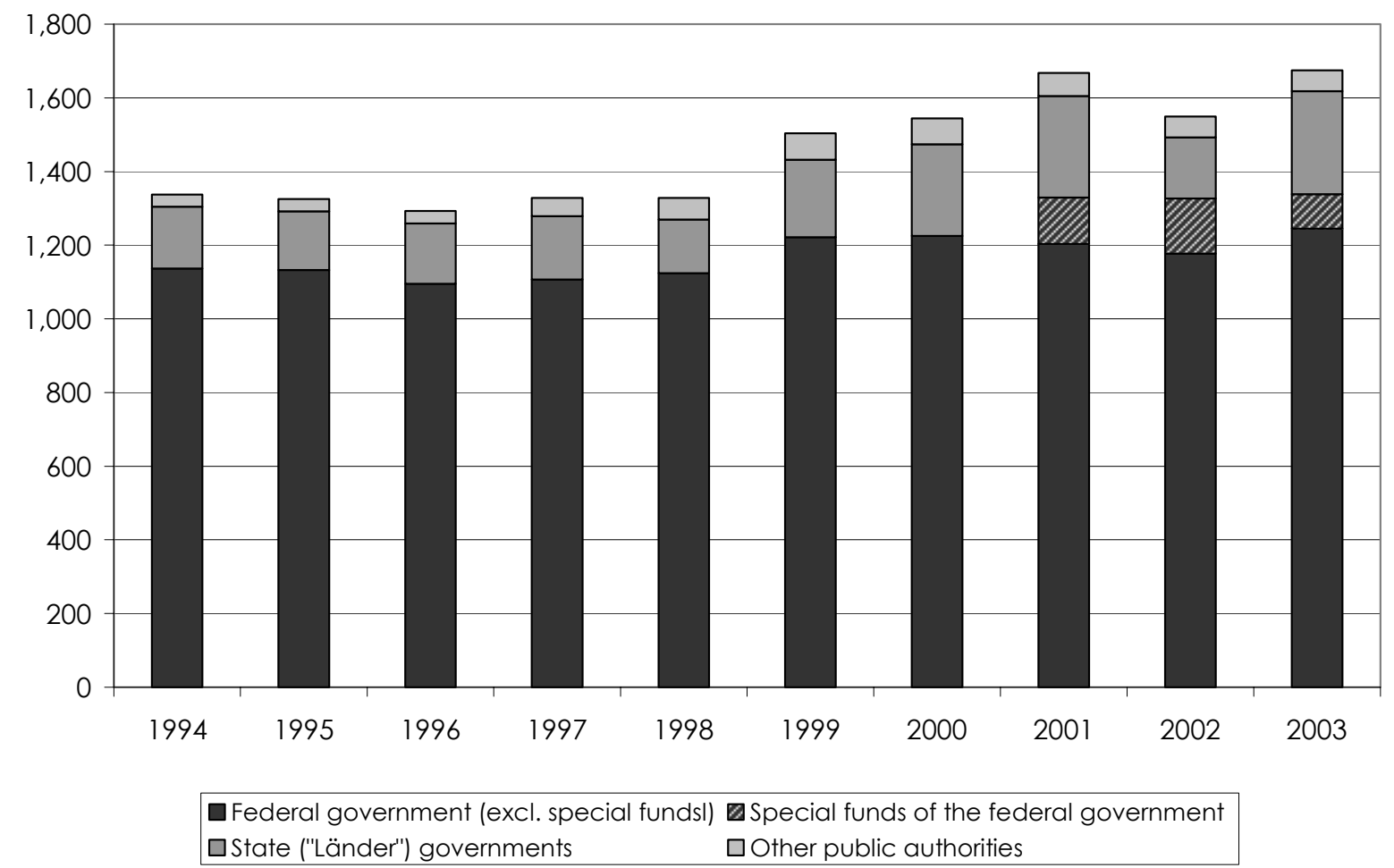

Source: Austrian Research and Technology Report, 2005, Table 1 and Tables 60 - 62; own calculations

In view of the large quantities of money that has been dedicated to already existing programs, it is worth to take a look at the composition of government financed R\&D 
over the last decade. Figure 1 shows that the ordinary federal budget for R\&D carried out in Austria was declining in 2001 and 2002. In 2003 federal government expenses excluding special funds rose again - but they exceeded the respective values of the years 1999 and 2000 by only $1.8 \%$ and $1.6 \%$, respectively. Considering the evolution of public funds throughout the entire ten-year period, the recent "special" funds initiative appears to be little more than a regular increase of public R\&D allowances.

A final note refers to the discrepancies between committed funds and disbursed funds (see Table 2). Though stated otherwise, less than three quarters of the special funds had actually been allocated by the end of 2003. The delay in disbursements involved some costs. Owing to the influence of inflation about $€ 5$ Mio were lost. This may appear as peanuts - yet it is about the same sum the Council allowed for R\&D co-operations with the New Member States ( $€ 5.01$ Mio) and more than was dedicated to the advancement of women in research and technology (€ $3.63 \mathrm{Mio})$.

Table 2: Special funds: commitment vs. disbursements (in Mio. €)

\begin{tabular}{l|rrrrr|r} 
& 2001 & 2002 & 2003 & 2004 & 2005 & Total \\
\hline Committed funds, current prices & 169.23 & 169.23 & 169.23 & 0.00 & 0.00 & 507.68 \\
Disbursed funds, current prices & 125.93 & 149.61 & 94.28 & 80.52 & 57.35 & 507.68 \\
& & & & & \\
Committed funds, constant pricea)s & 166.30 & 164.24 & 161.94 & 0.00 & 0.00 & 492.48 \\
Disbursed funds, constant pricesa) & 123.75 & 145.20 & 90.22 & 75.58 & 52.75 & 487.50 \\
\hline & \multicolumn{8}{|c|}{ Loss due to delay in disbursements } & 4.98
\end{tabular}

Source: Austrian Council for Research and Technology Development, Annual report 2000-2002 and Austrian Research and Technology Report, 2005, Tables 60 - 62; own calculations; a) $2000=100$

\section{Impact Assessment of Government Policies}

\subsection{Methodical Approach}

The well-known concept of additionality captures the extent to which firms change their RTI-inputs, -processes, or - outputs as a response to policy action. When policy action materialises in terms of funding, it is essential to know how much of this money is in fact additional at the outset. Figure 1 suggests that the special RTI-funds have replaced the regular budget appropriations to some degree. On this account we 
feel a certain discomfort with the existing micro-level evaluation studies (Schibany et al., 2004; Streicher et al., 2004). Since these are based on survey-data of the beneficiaries of these funds, they necessarily disregard the replacement effect. Our evaluation approach will therefore be conducted at the macro-level.

As is often the case in empirical work, you solve one problem, yet another new one arises. In this case the problem results from insufficient macro data. The Austrian practice of data collection and preparation in the fields of research, technology and innovation is anything but satisfactory. Though a supplement to the annual federal government budget (the "Beilage T") accounts for the entire sum of RTI-funds financed by the federal government, this report proves to be rather nontransparent. The main reason for this shortcoming is that the classification of the expenditure items sticks to the logics of the general budget and in most cases remain non selfexplanatory. Neither is it possibly to trace the moneys committed to various technology fields (such as biotech), nor can the figures be related to the three principle R\&D performance sectors (business enterprise sector, higher education sector, government sector). ${ }^{5}$ Every fourth year the federal statistical office takes up the effort to calculate these essential aggregates. In doing so, every expenditure item from the supplement report is classified "accordingly". It is impossible, however, to follow the calculations since the statistical office keeps back essential information on the classification.

To end up with a sample of relevant size, we make a strong assumption, viz. that the leverage effects of Austrian policy interventions on the business sector's R\&D intensity do not significantly deviate from the ones in other Western European countries. Accordingly, we estimate overall "European additionality coefficients" with data from the OECD's Main Science and Technology Indicators (MSTI) and then use these to make a projection on the effects Austria's recent special funds initiative.

\footnotetext{
5 Readers interested in the setup of the Beilage T may refer to Falk et al., 2004, chapter 3.
} 
Building on a highly acknowledged paper done by Guellec and van Pottelsberghe (2003), we model the impact of various public sector intervention measures on R\&D expenditures of the business sector as follows:

$$
\begin{aligned}
& \ln \left(\frac{\mathrm{BERD}_{\mathrm{it}}}{\mathrm{GDP}_{\mathrm{it}}}\right)=\beta_{\mathrm{i}}+\beta_{1} \ln \left(\frac{\mathrm{SUB}_{\mathrm{it}}}{\mathrm{GDP}_{\mathrm{it}}}\right)+\beta_{2} \ln \left(\mathrm{BINDEX}_{\mathrm{it}}\right)+\beta_{3} \ln \left(\frac{\mathrm{HERD}_{\mathrm{it}}}{\mathrm{GDP}_{\mathrm{it}}}\right)+\beta_{4} \ln \left(\frac{\mathrm{GOVERD}_{\mathrm{it}}}{\mathrm{GDP}_{\mathrm{it}}}\right) \\
& +\beta_{5} \ln \left(\frac{\mathrm{GDP}(\mathrm{PPP} \$)_{\mathrm{it}}}{\mathrm{L}_{\mathrm{it}}}\right)+\beta_{6} \ln \left(\frac{\mathrm{HTVA}_{\mathrm{it}}}{\mathrm{VA}_{\mathrm{it}}}\right)+\beta_{7} \mathrm{time}+\mathrm{u}_{\mathrm{it}} .
\end{aligned}
$$

The demand for total business sector R\&D expenditures (BERD) as a percentage of GDP is driven, first, by direct support in kinds of either grants and (subsidized) loans or through generous tax treatments of R\&D. The former is captured by $S U B_{i t} / G D P_{i t}$, government financed R\&D expenditures in the business sector as a percentage of GDP. The stimulating effect of fiscal incentives on the corporate sector's R\&D performance is evaluated by including Warda's B-index (Warda, 1996 and 2002). The value of the B-index depends on a country's income tax treatment of R\&D. The more favourable the tax treatment of R\&D, the lower is a country's B-index. Technically speaking, the B-index is calculated by dividing the after-tax cost (ATC) of a $\$ 1$ expenditure on R\&D by 1 less the corporate income tax rate $t$,

$B=A T C /(1-t)$, where $t=$ corporate income tax rate .

With respect to the more indirect public support measures GOVERD it $_{\text {it }} \mathrm{GDP}_{\text {it }}$ gives the ratio of intramural government sector R\&D expenditures to GDP6 and $H E R D_{i t} / G D P_{i t}$ denotes the ratio of R\&D expenditures within the higher education sector, again as a percentage of GDP.

\footnotetext{
6 The somewhat cumbersome concept of government intramural expenditure on R\&D captures research activities undertaken in institutions that do not purvey higher education and do not sell their output at an economical price. Instead, these institutions are generally controlled and mainly financed by the government, where control is the ability to determine the institution's general policy or programme by having the right to appoint its management. Even if the case of government control is not clear, such non-profit institutions are classified under GOVERD, if they are mainly financed by the government (see the Decision tree for sectoring R\&D units in the OECD's Frascati Manual, OECD (2002), chapter 3, figure 3.1).
} 
Finally, other than Guellec and van Pottelsberghe, we not only employ GDP per capita in constant PPP-\$ as a regressor, but their model is extended to capture the link between industry structure and R\&D. As a measure thereof we include a country's share of high tech manufacturing value added in total manufacturing value added $\left(\mathrm{HTVA}_{\mathrm{it}} / \mathrm{VA}_{\mathrm{it}}\right)$. Following the OECD's classification system, the former includes pharmaceuticals (ISIC Rev. 3 code is 2423), office, accounting and computing machinery (30), radio, television and communication equipment (32), aircraft and spacecraft (353) and medical, precision and optical instruments (33). For obvious reasons BERD is expected to be the higher the greater the inherent R\&D intensity of the industry structure. The point is not so much to verify a positive coefficient on the latter, but to control for the effects of a given R\&D intensity when evaluating the impact of various public intervention measures.

Contrary to the study of Guellec and van Pottelsberghe, we do not feed the model with annual data but use four-year averages. The rationale for doing so is first and foremost grounded in limited data availability: Austria reports the relevant figures on BERD, HERD, and GOVERD only periodically to the OECD.7 From a less technical point of view one may also argue that the B-index displays little variation from year to year and that only a longer period interval is suitable to capture the effects of changes in the fiscal system. Anyway, this average approach leaves us with up to six data points for each country (see Table 6 in the Appendix).

As for the estimation approach first the fixed effects within estimator has been employed and second a dynamic panel data model is applied using a one-step GMM estimator in first differences. ${ }^{8}$ Before proceeding to the empirical results, the next section presents some summary statistics on the variables of the model.

\footnotetext{
7 For that reason the study of Guellec and Van Pottelsberghe excludes Austria.

8 Originally, both specifications would also include slope dummies for Austria on SUB/GDP, BINDEX, HERD/GDP and GOVERD/GDP to allow the country of particular interest to deviate from the norm. Since the respective coefficients turned out insignificant without exception, they were eventually deleted in the final specification.
} 


\section{$4 \quad$ Summary Statistics and Descriptive Evidence}

Table 3: Evolution of R\&D expenditure items and their key determinants

\begin{tabular}{|c|c|c|c|c|c|c|c|}
\hline $\begin{array}{l}\text { Period } \\
\text { Austr. data avail. in }\end{array}$ & $\begin{array}{c}1980-83 \\
1981\end{array}$ & $\begin{array}{c}1984-87 \\
1985\end{array}$ & $\begin{array}{c}1988-91 \\
1989\end{array}$ & $\begin{array}{c}1992-95 \\
1993\end{array}$ & $\begin{array}{c}1996-99 \\
1998\end{array}$ & $\begin{array}{c}2000-03 \\
2002\end{array}$ & $\begin{array}{l}\text { Av. ann. } \\
\text { growth '81-02 }\end{array}$ \\
\hline & \multicolumn{6}{|c|}{ Gross domestic exp. on R\&D (GERD) as a \%-age of GDP } & \\
\hline Totala) & 1.38 & 1.51 & 1.58 & 1.68 & 1.80 & 2.02 & 1.83 \\
\hline \multirow[t]{2}{*}{ Austria } & 1.14 & 1.23 & 1.36 & 1.48 & 1.73 & 2.06 & 2.88 \\
\hline & \multicolumn{6}{|c|}{ Business enterpr. exp. on R\&D (BERD) as a \%-age of GDP } & \\
\hline Tota|a) & 0.84 & 0.94 & 0.98 & 1.02 & 1.11 & 1.28 & 2.07 \\
\hline \multirow[t]{2}{*}{ Austria } & 0.62 & 0.655 & 0.77 & 0.8 & 1.12 & 1.42 & 4.03 \\
\hline & \multicolumn{6}{|c|}{ Higher edu. exp. on R\&D (HERD) as a \%-age of GDP } & \\
\hline Totala) & 0.29 & 0.30 & 0.32 & 0.38 & 0.41 & 0.44 & 1.98 \\
\hline \multirow[t]{2}{*}{ Austria } & 0.36 & 0.42 & 0.43 & 0.5 & 0.52 & 0.57 & 2.21 \\
\hline & \multicolumn{6}{|c|}{ Gov. intramural exp. on R\&D (GOVERD) as a \%-age of GDP } & \\
\hline Totala) & 0.26 & 0.27 & 0.27 & 0.26 & 0.27 & 0.26 & -0.04 \\
\hline \multirow[t]{2}{*}{ Austria } & 0.1 & 0.1 & 0.1 & 0.13 & 0.11 & 0.12 & 0.87 \\
\hline & \multicolumn{6}{|c|}{ Gov. financed BERD as a percentage of GDP } & \\
\hline Totala) & 0.15 & 0.15 & 0.13 & 0.10 & 0.08 & 0.08 & -3.04 \\
\hline \multirow[t]{2}{*}{ Austria } & 0.05 & 0.05 & 0.04 & 0.08 & 0.06 & 0.08 & 2.65 \\
\hline & \multicolumn{6}{|c|}{ B-index (generosity of the tax system) } & \\
\hline Totala) & 0.99 & 0.99 & 0.99 & 0.98 & 0.96 & 0.93 & -0.28 \\
\hline \multirow[t]{2}{*}{ Austria } & 0.93 & 0.99 & 0.98 & 0.92 & 0.90 & 0.88 & -0.31 \\
\hline & \multicolumn{6}{|c|}{ GDP per cap. in 1,000 const. ppp-\$ (base year: 2000) } & \\
\hline Totala) & 23.94 & 21.97 & 21.75 & 21.83 & 24.24 & 26.69 & 0.52 \\
\hline \multirow[t]{2}{*}{ Austria } & 18.60 & 19.61 & 22.44 & 23.68 & 26.02 & 28.99 & 2.14 \\
\hline & \multicolumn{6}{|c|}{ Share of high high-tech in manufacturing value added } & \\
\hline Totala) & 7.93 & 8.84 & 9.70 & 10.80 & 11.66 & 12.79 & 2.30 \\
\hline Austria & 7.65 & 9.03 & 9.99 & 10.26 & 9.91 & 10.29 & 1.42 \\
\hline
\end{tabular}

Source: OECD MSTI and OECD STAN; a) unweighted average (

Table 3 displays mean figures on R\&D expenditure items in selected sub-periods for Austria and (unweighted) averages of these for the total sample, respectively. 
Austria's position in total R\&D spending has significantly improved throughout the entire period. With an average annual growth rate of $2.88 \%$ throughout the 1981 2002 period, its most recent GERD/GDP-ratio in fact outperforms the average R\&Dratio of the total European sample. Looking at gross R\&D expenses by R\&Dperforming sectors it becomes evident that the bulk of R\&D projects are increasingly undertaken by the business sector. By 2000-2003 the respective share comes up to over two-third in Austria, and is a tiny bit lower within the total European sample. While about $30 \%$ of Austria's gross domestic R\&D expenditures are made up of HERD throughout the last two decades, government intramural R\&D expenditures play only a minor and in fact a diminishing role. The slight increase therein stands vis-à-vis a declining share in Austria's gross R\&D expenditures. For the total European sample, government expenditures on R\&D are falling throughout the 1981-2002 period, both in absolute and in relative terms, but the mean value of GOVERD in GDP still accounts for $13 \%$ in the last period

Given the significance of business R\&D as a key component in total R\&D activities, it is worth asking about the trend in respective government support, including direct R\&D subsidies, as well as fiscal incentives. With respect to the former, government financed BERD generally proves to be very low; in 2000-2002 it amounted to only $0.08 \%$ in both samples. Note that the respective ratios are converging throughout time, i.e. for the total European sample the ratio of government funded BERD to GDP has constantly been decreasing during the last two decades, while Austria has been increasing its direct R\&D subsidies within the same time span. Figure 2 gives an illustration of the sources of the latest increase: it is entirely born by the special funds. In fact, on the financing side the special funds crowd out parts of the government's regular funds to the business enterprise sector, thus supporting our initial supposition that they substitute parts of the regular budget. 
Figure 2: Austrian Government financed BERD as a \%-age of GDP

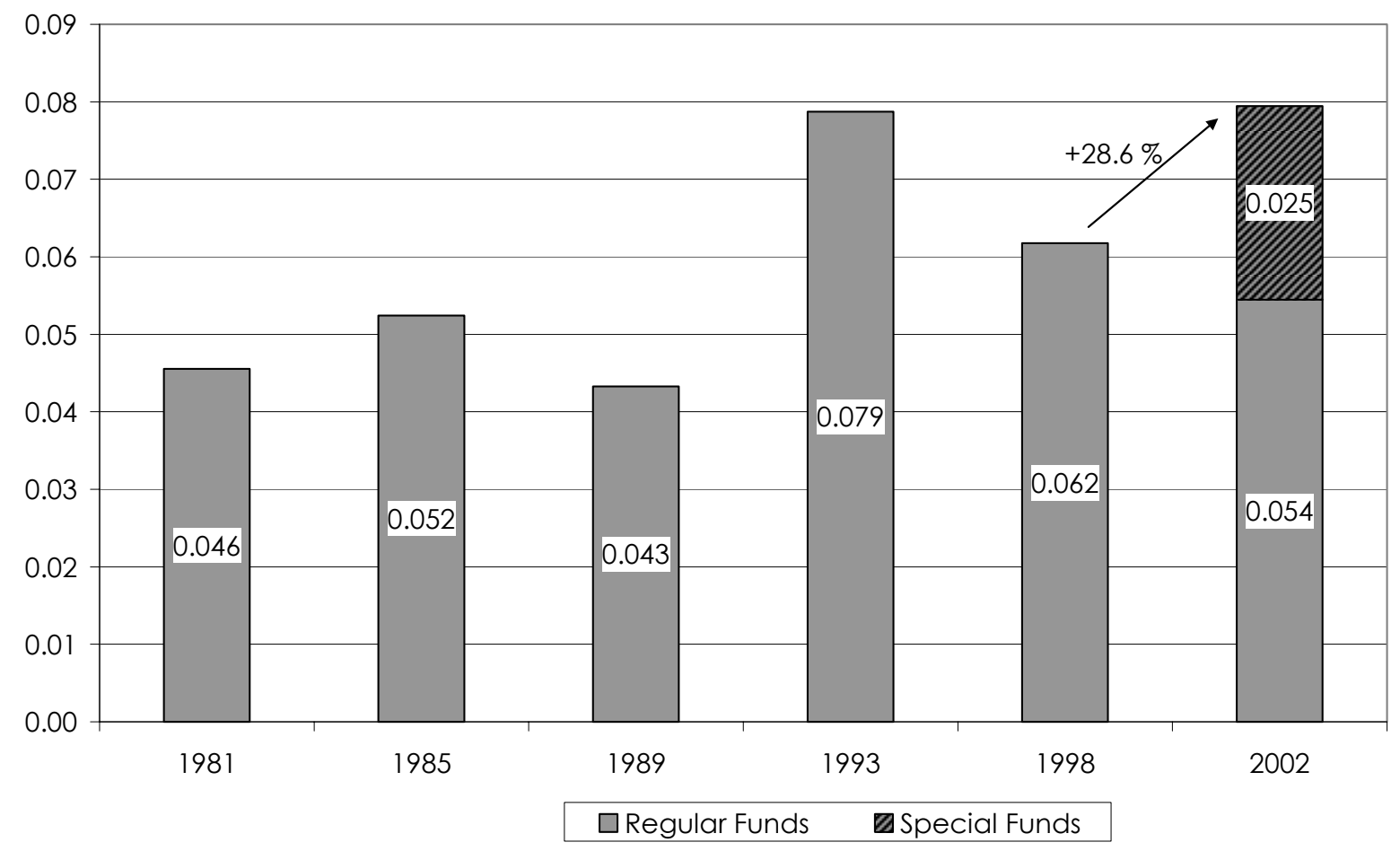

Source: MSTI and Austrian Research and Technology Report, 2005, Tables 60-62; own calculations.

Table 3 shows that Austria's tax policies reward R\&D performers relatively generously as compared to the European average. 9 In particular from 2000 onwards the business sector appreciates various kinds of tax incentives when undertaking research projects (see Heitzinger/Silber, 2003). Companies may deduct up to $25 \%$ (instead of up to $12 \%$ before 2000) of their R\&D expenditures from their profit-beforetax statements, thus reducing the basis for taxation. Alternatively, a tax allowance is granted for "economic useful inventions", which allows for a broader recognition of respective expenditures.

Overall, Austria's position in respect of several direct and indirect public intervention measures in favour of corporate R\&D performance seems quite promising. A

\footnotetext{
9 Hall and van Reenen (2000) present an overview of the tax treatment of R\&D across 26 (mostly OECD) countries. For a more up-to-date survey for Austria, compare Hutschenreiter (2002).
} 
dampening effect is most likely to result from the below-average R\&D-intensity of the industry structure. Figure 3 presents some bivariate evidence on the relationship between business sector R\&D expenditures and industry structure. The two variables in concern are positively correlated, as one would certainly expect.

Figure 3: Correlation between business sector R\&D expenditure and industry structure

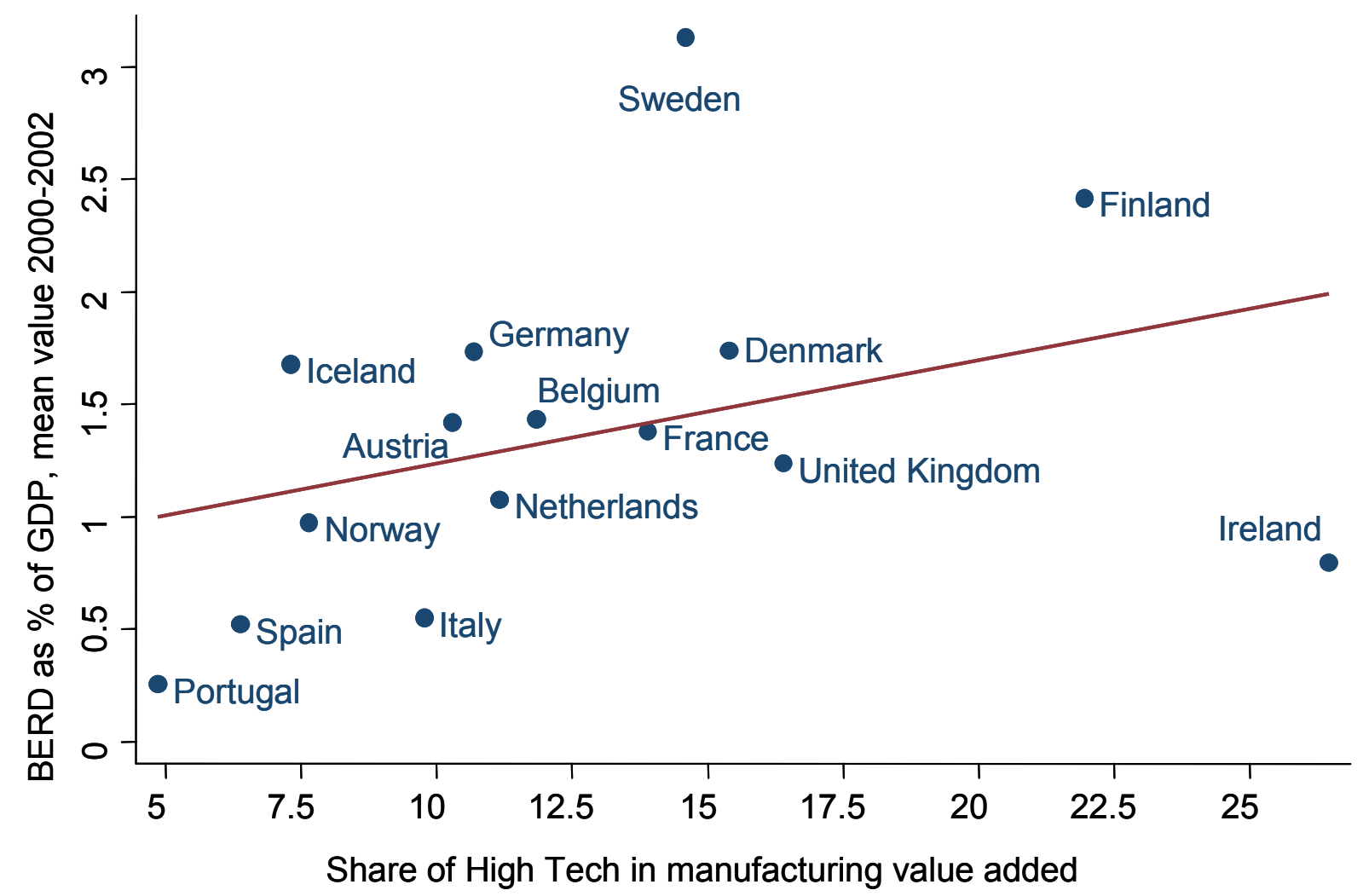

Source: MSTI/OECD, own calculations 


\section{$5 \quad$ Results}

Table 4 present the results of both estimation approaches to the model as specified in section 3.2. We find, first, that indirect support, such as increasing government intramural R\&D expenditures or R\&D-expenditures in the higher education sector, have no direct bearing on the R\&D intensity in the business sector.

Table 4: The impact of public intervention measures on business sector R\&D

\begin{tabular}{|c|c|c|c|c|c|}
\hline & & $\begin{array}{r}\text { Fixed } \\
M\end{array}$ & $\begin{array}{l}\text { ffects } \\
\text { del }\end{array}$ & $\begin{array}{l}\text { dynami } \\
\text { data }\end{array}$ & $\begin{array}{l}\text { panel } \\
\text { odela) }\end{array}$ \\
\hline $\begin{array}{l}\text { Nature of } \\
\text { Public R\&D }\end{array}$ & & Coeff. & t-value & $\begin{array}{l}\text { Short-run } \\
\text { Coeff. }\end{array}$ & t-value \\
\hline Support & Log BERD as $\%$ of GDP $\left.(t-1)^{b}\right)$ & & & 0.383 & 1.86 \\
\hline Direct & $\begin{array}{l}\text { Log government funded BERD as \% GDP(t) } \\
\text { (implied long-run effect)c) }\end{array}$ & 0.237 & 3.82 & $\begin{array}{r}0.155 \\
(0.252)\end{array}$ & 2.36 \\
\hline & Log B-index (t) & -1.270 & -3.97 & -1.330 & -3.99 \\
\hline Indirect & Log HERD as \% of GDP (†) & 0.022 & 0.15 & 0.098 & 0.48 \\
\hline & log GOVERD as \% of GDP ( $(t)$ & 0.110 & 0.89 & -0.063 & -0.52 \\
\hline Implicit & log GDP per capita (†) & 0.319 & 2.13 & 0.342 & 2.41 \\
\hline & log high-tech share in total manuf. (t) & 0.547 & 5.7 & 0.339 & 3.27 \\
\hline & Period dummy 1984-1987 & 0.065 & 1.31 & & \\
\hline & Period dummy 1988-1991 & 0.109 & 1.99 & & \\
\hline & Period dummy 1992-1995 & 0.110 & 1.59 & -0.048 & -0.86 \\
\hline & Period dummy 1996-1999 & 0.105 & 1.31 & -0.068 & -0.80 \\
\hline & Period dummy 2000-2003 & 0.166 & 1.69 & -0.064 & -0.53 \\
\hline & Constant & -1.713 & -3.96 & 0.002 & 0.050 \\
\hline & number of observations (countries) & & & 521 & \\
\hline $\begin{array}{l}\text { Goodness } \\
\text { of fit } \\
\text { measures }\end{array}$ & $\begin{array}{l}\mathrm{R}^{2} \text { (within) } \\
\text { Share of predicted in actual average annual } \\
\text { growth rate of (BERD as \% of GDP)d) }\end{array}$ & & & 0.8 & \\
\hline $\begin{array}{l}\text { Measures } \\
\text { of model } \\
\text { Specification }\end{array}$ & $\begin{array}{l}\text { F-test ( } p \text {-value) } \\
\text { Sargan Test } \chi^{2}(9) \text { (marg. signif. level) } \\
\text { Test } 2^{\text {nd }} \text { degree serial cor. (marg. sign. level) }\end{array}$ & 29.8 & $0.000)$ & $\begin{array}{l}26.911 \\
10.161 \\
0.3810\end{array}$ & $\begin{array}{l}.000) \\
.338) \\
704)\end{array}$ \\
\hline
\end{tabular}

a) The dynamic panel data model is estimated using the one-step GMM estimator in first differences.;

b) Significant at the 7 percent level; c) Calculated as short-run effect/(1-partial adjustment coefficient)

d) Predicted growthrate is derived from accumulating the fits of the significant regressors only and exludes time-dummies and constant. 
Since the appropriations to public research labs were declining during the period in question, the non-significance of the respective coefficient comes in fact as good news. On the other hand, the finding of insignificant coefficients of higher education research expenditures is puzzling. Authors such and Lederman and Maloney (2003) have shown that the quality of academic research institutions and collaboration between enterprises and universities are of eminent importance for increasing R\&D activities of the corporate world. Apparently, our empirical specification is too general in nature as to account for the diffusion of such effects. Though our model admittedly does not capture the spillover mechanisms, we can still conclude that RTI funding of the higher education sector is effective in raising a country's BERD intensity if and to the extent that such policies benefit a country's overall economic prosperity or contribute to structural change towards more R\&D-intensive manufacturing.

As for the more targeted policy measures, changes in fiscal incentives for R\&D as measured by the B-index do significantly impact on the demand for R\&D in the business sector. Elasticities between -1.27 (fixed effects specification) and -1.33 (dynamic GMM specification) indicates that a $1 \%$ reduction in the prices of R\&D (increase in generosity of tax incentives for R\&D) leads to an increase in the amount of R\&D of about 1.3\%. This finding is consistent with former evidence on the triggering effect of tax incentives, though arguably a bit on the high side. The European Commission (2003) in its recent report suggests a median price elasticity of -0.81 .

The estimated elasticities for government funded R\&D in the business sector range between 0.155 in the short-run and 0.252 in the long run. Note that the long-term effects from the dynamic setting come very close to the results of the static fixed effects approach. These elasticities translate into marginal effects of well above one for the entire period, 10 hence there is a complementary relationship between public subsidies and BERD, as one would hope.

\footnotetext{
10 The log-formulation of the above model implies that the estimated coefficients are to be interpreted as elasticities, i.e. $\varepsilon_{\mathrm{yx}}=\partial \ln \mathrm{y} / \partial \ln \mathrm{x}=(\partial \mathrm{y} / \mathrm{y}) \cdot(\mathrm{x} / \partial \mathrm{x})$. To calculate country- and time-specific marginal effects, the estimates are multiplied by $\left(\bar{y}_{i t} / \bar{x}_{i t}\right)$, i.e. the average $\left(y_{i t} / x_{i t}\right)$ for country $i$ in Period $t$,
} 


\subsection{The Effects of Austria's Special Funds for Research and Development}

Turning once more to the effects of Austria's Special Funds initiative, apparently only the money dedicated to the business enterprise sector will have an immediate bearing on this sector's R\&D expenditure. Between 1998 and 2002 government financed BERD as a percentage of GDP rose by $29 \%$. As was shown in Figure 2, this entire increase is due to the extra money from the special funds. With estimated elasticities between 0.155 in the short run and 0.252 in the long run, the induced increase in the BERD-GDP ratio is $4.5 \%$ (short run) and $7.3 \%$, respectively (long-run). Actual growth of the left hand-side variable in this period came up to $27 \%$ (from Table 3). Hence, about one-fifths of the growth in the R\&D-expenditure of the Business sector as percent of GDP can be directly related to the Special Funds initiative.

Table 5: Sources of change in Austrian BERD intensity

\begin{tabular}{|c|c|c|}
\hline & Static approach & Dynamic approach \\
\hline & $1981-2002$ & 1985-20021 \\
\hline Observed av. ann. change in (BERD/GDP) & 4.0 & 4.7 \\
\hline \multicolumn{3}{|l|}{ Contributions from ... in \% } \\
\hline$\ldots$ BERD/GDP (t-1) & & 29.1 \\
\hline ... Gov. funded BERD/GDP( $(\dagger)$ & 15.6 & 9.6 \\
\hline$\ldots$ B-Index $(t)$ & 10.4 & 19.7 \\
\hline ... GDP per capita ( $(t)$ & 16.9 & 17.1 \\
\hline ... High-tech share in manufacturing value added ( $(t)$ & 19.3 & 5.6 \\
\hline Sum & 62.2 & 81.1 \\
\hline
\end{tabular}

Note: calculations based on results of Table 4.

In the above exercise estimates for a 20 -year period are rigorously combined with presumed average values of the very last time period. Since the relationship $\frac{\partial \mathrm{y}_{\mathrm{t}}}{\mathrm{y}_{\mathrm{t}}} \approx \sum_{\mathrm{j}=1}^{\mathrm{J}} \varepsilon_{\mathrm{yx}_{\mathrm{j}}} \cdot \frac{\partial \mathrm{x}_{\mathrm{jt}}}{\mathrm{x}_{\mathrm{jt}}}$ (for all "policy measures" $\mathrm{j}$ ) holds for the entire period, arguably

where $y_{i t}$ denotes the $i$-ths country's mean BERD intensity in period $t$, and $x_{i t}$ is government financed BERD as a percentage of GDP. 
it makes more sense to ask how much of the observed change in the BERD intensity between the very first and the last period can be attributed to the respective actual changes of the explanatory variables $j$ of the model. While elasticities give an idea of the efficiency of both the direct and the implicit public support measures for R\&D, the following decomposition analysis (see Table 5) allows for conclusions on the efficiacy of either policy approach.

Table 5 shows that structural changes have had a greater impact on BERD as compared to more tightly focussed policy measures. This is especially true in the dynamic approach, when the lagged endogenous variable accounts for a considerable share of the predicted change in BERD (almost one third). By contrast, the stimulating effects of direct R\&D-support in kind of loans and grants seem to be modest.

\section{Concluding Remarks}

Based on a panel regression of 15 Western European countries for the period 19802002 , this paper evaluates the effectiveness of various support strategies in the fields of RT\&I. Though the estimates suggest that direct government subsidies to R\&Dperforming firms unfold great leverage effects, the dynamics of output growth as well as an R\&D-prone high-tech industry structure seem to be more important drivers of the business sector's R\&D intensity.

Several empirical studies on innovation activities have pointed at the rather low share of high-tech industries in Austrian value added or employment (Peneder et al. 2001, Austrian Science-and Technology Report, 2003). Irrespective of this technology gap it remains true that by international comparison aggregate trends in Austrian employment, growth, or national income have not evolved below average within the last three decades. Strangely enough, Austria even succeeded to increase its share in EU value added ("the Austrian paradox"). As Peneder notes, the technology gap is still to be taken seriously, because structural deficits in kind of little specialization in dynamic, technology-intensive sectors will dampen the long run 
perspectives of economic growth." At this point we add that an unfavourable industry structure does not only hamper long-term growth, but that the realization of intermediate aims such as an R\&D quota of $3 \%$ by 2010 is challenged as well.

These considerations call for a more strategic appropriation of public R\&D funds and for a more strategic approach to technology and innovation policy in general. The costly delays in actual disbursements and the disposition to sell existing RTI-programs as part of the special funds initiative (when actually only sources of funds have been replaced) reveal that Austria's trip to Barcelona is not well planned yet.

On the positive side, the recent abolishment of all inscription fees by the Chamber of Commerce is highly acknowledgeable as it reduces the start-up costs of new and innovative enterprises significantly. Similarly, the recent debate on intellectual property rights and the attempts to make them more incentive compatible goes in the right direction.

11) Austrian Science and Technology Report 2003, p. $23 \mathrm{ff}$. 


\section{Appendix}

Table 6: periods included by country

\begin{tabular}{l|c|c} 
Country & static model & dynamic model \\
\hline Austria & $1-6$ & $3-6$ \\
Belgium & $4-6$ & $5-6$ \\
Denmark & $1-6$ & $3-6$ \\
Finland & $1-6$ & $3-6$ \\
France & $1-6$ & $3-6$ \\
Germany & $1-6$ & $3-6$ \\
Iceland & $5-6$ & 6 \\
Ireland & $3-6$ & $4-6$ \\
Italy & $1-6$ & $3-6$ \\
Netherlands & $4-6$ & $5-6$ \\
Norway & $1-6$ & $3-6$ \\
Portugal & $1-6$ & $3-6$ \\
Spain & $1-6$ & $3-6$ \\
Sweden & $1-6$ & $3-6$ \\
UK & $1-6$ & $3-6$ \\
\hline number of obs. & 78 & 52
\end{tabular}




\section{References}

Austrian Council for Research and Technology Development (2002A), Annual report 2000-2002, Vienna, 2002.

Austrian Council for Research and Technology Development (2002B), National Research and Innovation Plan, Vienna 2002. Download at http://www.rat-fte.at/files/NFIP 20021203 eng.pdf

Austrian Council for Research and Technology Development (2003), Annual report 2002-2003, Vienna, 2003.

Austrian Council for Research and Technology Development (2005), Strategy 2010: Perspectives for Research, Technology and Innovation. Vienna 2005. Available at http://www.ratfte.at/UserFiles/File/Strategie2010_eng.pdf

Bloom, Nick, Rachel Griffith and John Van Reenen, Do R\&D Tax Credits Work? Evidence from a Panel of Countries 1979-97, Journal of Public Economics, Vol. 85, 2002, pp. 1-31.

BMBWK, BMVIT, BMWA (2003), Österreichischer Forschungs- und Technologiebericht Vienna, 2003.

BMBWK, BMVIT, BMWA (2004), Österreichischer Forschungs- und Technologiebericht, Vienna, 2004.

David, Paul A., B. Hall and A. Toole, Is public R\&D a complement or substitute for private R\&D? A review of the econometric evidence, Research Policy, Vol. 29 (2000), pp. 497-529.

European Commission (eds.), European Trend Chart on Innovation: Country Report - The Netherlands September 2002 - August 2003, 2003.

Falk, Rahel (2004), Behavioural additionality effects of R\&D subsidies: empirical evidence from Austria, tip working paper, February 2004.

Falk, Rahel and Hannes Leo (2004) „Finanzierung von Forschung und Entwicklung in Österreich durch den Bund und die EU", study on behalf of the Federation of Austrian Industry, October 2004, Vienna.

Georghiou, L., Smith, K., Toivanen, O., Ylä-Anttila, P., Evaluation of the Finnish Innovation Support System, Helsinki 2003.

Goolsbee, A., Does government R\&D policy mainly benefit scientists and engineers?, American Economic Review, Vol. 88, pp. 298-302, 1998.

Guellec, D., Van Pottelsberghe, B., The impact of public R\&D expenditure on business R\&D, Eonomics of Innovation and New Technology, forthcoming, vol. 12, 3, pp. 225-244, 2003.

Hall, B., van Reenen, J., How effective are fiscal incentives for R\&D? A review of the evidence, Research Policy, Vol. 29, 2000, pp. 449-469.

Heitzinger, F., Silber, G., J., Forschungsfreibeträge und Forschungsprämie, Auslegungsfragen und Gestaltungsmöglichkeiten im österreichischen Steverrecht, Wien 2003. 
Hutschenreiter, G., Polt, W., Gassler, H., Möglichkeiten zur Erhöhung der österreichischen Forschungsquote - Abschätzung der Effekte öffentlicher auf private F\&E-Ausgaben, WIFO Joanneum Research, Wien, 2001.

Hutschenreiter, G., Steuerliche Förderung von Forschung und Entwicklung, WIFO-Monatsberichte, 2002, Vol. 75(2), 2002, pp. 121-131.

Lederman, D., W., F., R\&D and Development, World Bank Policy Research Working Paper No. 3024, Worldbank, Washington D.C. 2003.

Leo, H., Schwarz, G., Geider, M., Pohn-Weidinger, S., Polt, W., Die direkte Technologieförderung des Bundes, WIFO - Joanneum Research, Wien, 2002.

Leo, H., Ziegler, E., European Trend Chart on Innovation, Annual Policy Trends and Appraisal Report for Austria, September 2003-August 2004, European Commission, Enterprise Directorate-Genera at www.trendchart.cordis.lu n, 2004.

OECD (Directorate for Science, Technology and Industry), STI Outlook - Country Response to Policy Questionnaire, Canada 2002.

OECD (Directorate for Science, Technology and Industry), STI Outlook - Country Response to the Policy Questionnaire, 2002.

OECD, Frascati Manual: Proposed Standard Practice for Surveys on Research and Experimental Development, OECD : Paris, 2002.

OECD, Main Science and Technology Indicators - Principaux indicateurs de la science et de la technologie, Vol. 2003, No. 2, OECD : Paris, 2004.

OECD, Main Science and Technology Indicators - Principaux indicateurs de la science et de la technologie, Vol. 2003, No. 2, OECD : Paris, 2004.

OECD: STAN database for Industrial Analysis, Vol. 2004 release 03, OECD: Paris, 2004.

Peneder, M. (2001), Aiginger, K., Hutschenreiter, G., Marterbaver, M., Structural Change and Economic Growth, WIFO, 2001.

Peneder, M., Industrial structure and aggregate growth, Structural Change and Economic Dynamics, Vol. 14, pp. 427-448, December 2003.

Prihti, A., L. Georghiou, E. Helander, J. Juusela, F. Meyer-Krahmer, B. Roslin, T. Santamäki-Vuori, M. Gröhn, Assessment of the additional appropriation for research, Sitra Reports Series 2, Helsinki, 2000.

Prihti, Aatto, Georghiou, Luke, et al.: Assessment of the additional appropriation for research, Sitra Reports series 2, Helsinki 2000.

Schibany, A., G. Streicher, N. Gretzmacher, M. Falk, R. Falk, N. Knoll, G. Schwarz, M. Wörther, Evaluation FFF: Impact analysis - Background report 3.2, ETH, Joaneum Research and WIFO, Vienna, 2004. 
Streicher, G., Schibany, A., Dinges, M., Gretzmacher, N. Evaluation FWF: Impact analysis - Background report 4.2, Joaneum Research, Vienna, 2004.

Technopolis, An Evaluation of the RTDI for Collaboration Programme. Brighton et al., June 2004

Van Pottelsberghe, B., Nysten, S., Megally, E., Evaluation of current fiscal incentives for business R\&D in Belgium, SSTC and CEB Working Paper, Solvay Business School, ULB, 2003.

Van Pottelsberghe, B., Nysten, S., Megally, E., Evaluation of current fiscal incentives for business R\&D in Belgium, SSTC and CEB Working Paper, Solvay Business School, ULB, 2003.

Warda, J., A 2001-2002 update of R\&D tax treatment in OECD countries, report prepared for the OECD Directorate for Science, Technology and Industry, Paris: OECD, 2002.

Warda, J., Measuring the values of R\&D tax provisions, in: OECD (ed.), Fiscal measures to promote R\&D and innovation, Paris: OECD, 1996, pp. 8-22. 


\section{(C) 2006 Österreic hisc hes Institut für Wirtsc haftsforsc hung}

Medieninhaber (Verleger), Hersteller: Österreic hisc hes Institut für Wirtsc haftsforsc hung • Wien 3, Arsenal, Objekt 20 • A-1103 Wien, Postfach 91 • Tel. (43 1) 79826 01-0 • Fax (43 1) 7989386 • http://www.wifo.ac.at/ • Verlags- und Herstellungsort: Wien

Die Working Papers geben nicht notwendigerweise die Meinung des WIFO wieder

Kostenloser Download:

http://publikationen.wifo.ac.at/pls/wifosite/wifosite.wifo_search.get_abstract_type?p_language=1\&pubid=26621 